\title{
FROM CONSTANCE OOSTHUIZEN TO PURITY MALINGA: THE STRUGGLE FOR EQUALITY IN ORDINATION IN THE METHODIST CHURCH OF SOUTHERN AFRICA
}

\author{
Raymond Simangaliso Kumalo \\ University of KwaZulu-Natal \\ Seth Mokitimi Methodist Seminary \\ kumalor@smms.ac.za
}

\section{ABSTRACT}

The researcher believes that while in the Methodist Church of Southern Africa (MCSA) women have been ordained to the ministry of Word and Sacrament since 1976, they remain a minority numerically and are still marginalised in leadership. As a result ordained women remain the most unrecognised and underutilised group in the MCSA. Few women ministers have held leadership positions during this period, particularly primary leadership positions. This article enquires into the experiences (or, 'acceptance') of these women, the reasons for the minority representation, and reflects on the future of representative ordained ministry. A theoretical framework of feminist ecclesiology is used as an approach. Primary research provides statistical data upon which the assessment of progress towards gender equality is based. The impact of culture upon institutional gender representation is discussed, together with equality of opportunity in principle and practice. Reference is made to gender equality in other institutions, both secular and religious. The article reflects upon the leadership of the MCSA towards gender equality in the ordained ministry, and some conclusions are drawn and recommendations suggested for the future.

Keywords: Methodist Church of Southern Africa; women ordination; gender equality; leadership

\section{UNISA}




\section{INTRODUCTION}

In the town of Pietermaritzburg, which is located in the South African province of KwaZulu-Natal, stand the monumental and magnificent buildings of the Seth Mokitimi Methodist Seminary (SMMS), which is the pride of the Methodist Church of Southern Africa. At the centre of the SMMS buildings stands the Christ the Servant Chapel with its large doors. Behind the chapel is a beautiful, evergreen and tranquil prayer garden, built with cubicle hedges and strong pews. In the entrance of the garden is a stone with these words: 'This garden remembers the witness of the Methodist women and honours the first woman to be ordained in the MCSA, Rev. Constance Oosthuizen, and the first woman Bishop, Rev. Purity Malinga.' ${ }^{1}$ The prayer garden serves as a reminder of the sacrificial service that has been given by women ministers in the life of the Methodist Church since the ordination of the first woman minister; and also to celebrate the milestone achievement when a woman was elected as the first bishop of the Methodist Church and of a mainline denomination in South Africa.

Against this backdrop of reverence for the role of women in the MCSA, this article is based on a research study which endeavoured to explore the leadership role of women in the MCSA further.

\section{RESEARCH FRAMEWORK}

\section{Purpose}

There are three objectives for this research. The first is to obtain quantitative information on the experiences of women ministers in the MCSA. Second, the research sets out to appraise the work of the MCSA in enabling the ministry of women and seeking the subversion of patriarchal tendencies within itself. Third, the researcher hopes to offer encouragement to the church to review its structures, systems and beliefs that continue to stifle the growth of women leaders in the church. The research was first initiated by the third year leadership class of 2015 at Seth Mokitimi Methodist Seminary. A group of four students formed a research team under the leadership of the researcher, who was their lecturer at the time. ${ }^{2}$

1 Seth Mokitimi Methodist Seminary Brochure 2016, 21.

2 The names of the students who participated in this research are Revs Carol Lubbe, Thembeka Cira, David Rose and Eric Setshedi. All these former students are now pastoring various congregations in the Connexion. It was mostly through their commitment and work as research assistants that the paper came into being. Therefore this paper is dedicated to them. 


\section{THE PROBLEM}

The critical question that the research seeks to respond to, is the experience of women ministers in the MCSA since the church resolved to ordain them 40 years ago. The aim is to critically evaluate the work that has been done by the MCSA in developing equality of ministry amongst its ordained ministers. In short: Are male and female ministers treated equally in the MCSA? Do they have equal access to rights, privileges and opportunities to leadership positions? These questions are more relevant in an African cultural context - where the MCSA is located and church leaders are generally patriarchal - factors which are bound to affect the roles of women, especially when it comes to leadership. Nevertheless, in spite of the fact that women are the majority in society and in the church, men tend to dominate leadership roles with women playing subservient ones. Generally when one studies and understands most of the African cultures in the Methodist connexion, men and women are not understood as equals. There is much evidence of gender inequality, which is traditionally part of those cultures and makes it difficult for men and women to suddenly work together as equals or to even see a woman as a superior of a male colleague. Both men and women have been brought up within this framework of belief in gender inequality.

Culturally men have internalised the prejudices against women and women have learnt to conform to what is expected of them to the extent that they do not seek to change. ${ }^{3}$

The MCSA has a history of women fulfilling leadership roles from as far back as the days of John Wesley, the founder of Methodism; although this was not without its challenges. ${ }^{4}$ For instance, Wesley licensed Sarah Crosby to preach as far back as 1761. However, in South Africa women were relegated to the positions of deacons and leaders of women's groups. This position was only changed officially in 1975 when the conference of the MCSA took the decision to ordain women into the ministry of Word and Sacrament and to be accepted into full connexion, ${ }^{5}$ which is an admission to the fellowship of all Methodist ministers and the right to minister in any Methodist church that falls under the connexion. ${ }^{6}$ The debate on the ordination started in 1973, when the Rev. Jack Cook who was the warden of the Deaconess

3 Runyoro, W., Rangarari, R., Erasmus, J, and Hendriks, J. Resource development and women in leadership position in the Reformed Church of Zimbabwe. Missionalia 29(3), (November 2001): 520-536.

4 Winslow, K. Wesleyan perspectives on women in ministry. Azusa Pacific University July 2005: 1.

5 Warner, L. The method of our mission: United Methodist polity and organization. Nashville: Abingdon, 211: 8 .

6 Connexion is a 'vital web of interactive relationships...that includes the agencies of the church, with the purpose of equipping local churches for ministry by providing a connection for ministry throughout the world, all to the glory of God'. The Book of Discipline (quoted in Warner The method of our mission: United Methodist polity and organization, 8. 
Order then, tabled a resolution at a conference for the church to ordain women who were serving as deaconesses. ${ }^{7}$ The fact that it took the MCSA a number of years in deliberating on the resolution to ordain women - and there were some who were vigorously opposed to the resolution - demonstrates the level of patriarchy and the relegation of women to lower levels in the life of the church, which was prevalent at the time.

\section{Hypotheses}

In this study the researcher and his assistants held the following hypotheses:

- Women ministers are experiencing inequality of ministry in the MCSA.

- Women ministers are under-represented in the leadership structures.

\section{Theoretical framework and methodology}

The theoretical framework for this article is 'feminist of ecclesiology'. Feminist of ecclesiology is the discipline that promotes equality for all people and inclusion in the church. Natalie Watson says: 'Ecclesiology as a theological discipline was born out of a historical need, a situation which made it necessary for the church to define itself. ${ }^{8}$ She further observes that 'a feminist reconsideration of ecclesiology is an act of reclaiming an area of theology and the life of the church that in the past has been largely a male domain'. ${ }^{9}$ However, it is also important to note that, when the story of the church is studied from a feminist perspective, it calls for the consideration of the context of that particular church. Therefore feminist ecclesiology cannot be complete without considering the context. The church, as ecclesiology discusses it, is both 1) A spiritual entity - something which Christians believe to be one, holy, Catholic and apostolic; and 2) An institution - a political body which is divided into denominations. ${ }^{10}$ The writing of ecclesiology takes place within a particular political situation, usually that of a particular denomination. In this case the focus is the MCSA. Watson states that:

The task of feminist ecclesiology is twofold; it does not involve thinking and speaking theological about the church as an institution and about particular institutions in which the church exists, but it goes beyond this focus on the institution in discussing a variety of different models by which the church describes itself in theological terms. ${ }^{11}$

7 Oosthuizen, C. Conquerors through Christ. Jeppestown: Methodist Church 1990, 75.

8 Watson, N. Introducing feminist of ecclesiology. London: Bloomsberry, 2002, 4.

9 Watson, N. Introducing feminist of ecclesiology, 6.

10 Watson, N. Introducing feminist of ecclesiology, 8.

11 Watson, N. Introducing feminist of ecclesiology, 9. 
The MCSA associates itself with the theory of 'priesthood of all believers' as preached and accepted by many Protestant churches. The concept of the priesthood of all believers stems from the assumption that every believer has direct access to God without ecclesiastical mediation and each Christian (man or woman) shares the responsibility of ministering to other members of the community, as stated in 1 Peter 2:9: But you are a royal priesthood, a holy nation, a people belonging to God, that you may declare the praises of him who called you out of darkness into the light. Watson further says that "women cannot be content with simply being assured that they are part of the church as a spiritual body; their presence and participation has to be expressed in the very structures in which the church as the embodiment of triune God is manifesting himself'. ${ }^{12}$

\section{The research methodology}

This project involved both field work and library study. It also involved statistics of leadership in the MCSA in terms of gender. Two interview methods were used, namely formal face-to-face interviews as well as a questionnaire. The face-to-face interviews were conducted extensively with more than 20 candidates and they were selected because they enabled deeper discussions and interactions between the interviewers and interviewees. This type of research method was deemed appropriate for this research because the researchers were able to follow up on interviewees in cases where there was a need for clarity; and that strengthened the research process. Five students interviewed five Methodists women ministers each. A large amount of data, for example historical facts and statistics were gleaned from reports and the Minutes of the Methodist Conference 1973, 1974, 1975.

There are three types of sampling: convenience sampling, random sampling and purposive sampling. For this research, respondents were Methodist women ministers who are in active service in the MCSA Connexion. Respondents were selected for theoretical reasons. Hence, the researchers chose to utilise a purposive sampling method, because participants had to be selected according to the requirements of being Methodist women ministers.

The MCSA has a seminary in Pietermaritzburg and all 10 women seminarians were interviewed. The other 10 were women ministers from all over the Connexion. In that sense, the researchers anticipated that their views would also partly represent the views of women ministers in the Methodist Church. Since the researchers were themselves Methodists, they felt that this was an advantage in identifying interviewees with some relative ease, and in ensuring that the research outcomes would indeed represent the views of the majority of those interviewed.

12 Watson, N. Introducing feminist of ecclesiology, 8. 


\section{THE MCSA AND PATRIARCHY}

John Wesley, the founder of Methodism, was a realist and a reasonable man whose opinions on the inclusion of women in ministry evolved over time and influenced his practice, as he responded to his world and to the needs and gifts of those in his large parish.

Initially he denounced the Quaker practice of allowing women to preach to a church assembly, but in his 'Explanatory notes upon the New Testament', he qualified 1 Corinthian 14:34-35 and 1 Timothy 2:12-15. He warned that women must be quiet 'unless they are under an extraordinary impulse of the Spirit'. ${ }^{13}$ Wesley observed the effectiveness of women speaking in the cells and he had to wrestle with the difference between women 'exhorting' or 'testifying' and 'preaching'. ${ }^{14}$ While John Wesley, for the most part, did not technically allow women to preach ('exhort'), he did recognise and encourage women to be leaders in a variety of ways. ${ }^{15}$

When he decided to allow women to play leadership roles in the Methodist movement Wesley was attacked from inside and outside of Methodism for his actions. In London, for example, some of Wesley's followers tried to exclude women from a number of the society's activities. Their actions infuriated Wesley, who told them that he did 'exceedingly disapprove' 16 of excluding women when the society met to pray, sing, and read the Scriptures. Charles Yrigoyen observes:

Methodists flourished under the direction of class and band leaders, persons of spiritual strength and insight. Most of them were women! Among them were Sarah Crosby, Dorothy Downes, and Grace Murray, exemplary Christians whose witness persuaded many to accept God's grace and begin a new life...In effect, Sarah Crosby, Mary Bosanquet, Hannah Harrison, Eliza Bennis, Jane Cooper, and others...were engaged in preaching, and many people experienced conversion as a result of their testimony and proclamation of the gospel... In 1787, despite the objections of some of the male preachers, he officially authorized Sarah Mallet to preach, as long as she proclaimed the doctrines and adhered to the disciplines that all Methodist preachers were expected to accept. ${ }^{17}$

Wesley was a reformer in regard to women in ministry. His assumption was that Paul forbade women to preach, but his experience demonstrated that women were some of the best preachers and pastors. ${ }^{18}$ He noticed that Paul's experience included

13 John Wesley's 'Explanatory notes upon the New Testament'. In Warner, L. The method of our mission: United Methodist polity and organization, 175.

14 Ibid.

15 Wesley received much of his early spiritual and academic training from his mother, Susanna Wesley. The fact that Susanna was a strong, intelligent, spiritually mature woman may also be a reason why Wesley supported such women leaders in the Methodist movement.

$16 \mathrm{http} / /$ www.christianitytoday.com/history/issues/issue-2/john-wesley-and-women.htmlBu John Wesley and Women | Christian History.

17 Yrigoyen, J. John Wesley: Holiness of heart and life. Nashville: Abingdon Press, 1996, 8.

18 Ibid. 
women praying and prophesying in the church. Thus, at first Wesley encouraged women touched by God to 'testify' and avoided the word 'preach'. Later he claimed the movement of God of his day was an extraordinary situation similar to the Acts 2 narrative where God was clearly no respecter of persons in pouring out the Spirit. $\mathrm{He}$ began encouraging women to preach in society meetings.

Before the end of his life and ministry he finally began to ordain women into the ministry. The first two women in the Methodist movement were Sarah Mallet, an effective Methodist preacher, and Sarah Crosby, who was a tireless itinerant preacher. This was the beginning of the ordination of women in the tradition of the Methodist Church. It is unfortunate that after Wesley's death opportunities for women to minister publicly, quickly declined. ${ }^{19}$

\section{A historical development of woman ordination in the MCSA}

Methodism first arrived in South Africa in 1795. The first ordained person to arrive was the Rev. McKinney, who arrived in 1813. The church ordained male ministers and had lost Wesley's practice of ordaining women. As a result, women were kept on the outside or on the periphery of 'the Institutional church' and could not often occupy leadership positions, even though they were at the heart of the building of the churches, evangelism and providing physical and financial support to the mission work.

It was only in 1973 that the issue of the ordination of women in the MCSA was brought to the attention of Conference. This was when the warden of the Deaconess Order of the MCSA, Rev. A.J. Cook, put forward the proposal for the admission of women to the ministry of Word and Sacrament. He was moved and encouraged by the work of Constance Oosthuizen, who had worked as a deaconess for over 20 years, where she had built congregations, church buildings and church halls in Turfontein Johannesburg, but had been denied admission to the order of Presbyters. ${ }^{20}$ This resolution was only accepted in the Conference of 1975, simply because there was vigorous debate and opposition. In 1975 both Constance Oosthuizen and Dorothy Spink were accepted as candidates. The MCSA decreed that women would be ordained to the ministry of Word and Sacrament in $1976 .{ }^{21}$ Constance Oosthuizen was ordained in 1976, after one year probation because she had already served as deaconess for 21 years. Dorothy Spink, who candidated for ministry prior to her ordination as deaconess, was ordained in 1978. Mavis Mbilini candidated for

19 Tucker, R. Daughters of the church. Grand Rapids: Academia Books, 1987, 240.

20 New Dimension. Celebrating the Rev. Constance Oosthuizen. New Dimension 47(7), (August 2016): 1. Johannesburg.

21 Oosthuizen, Conquerors in Christ, 75 
ministry a year after she was ordained as deaconess and was ordained to the ministry in 1985, being the first black woman Methodist minister. ${ }^{22}$

For almost four decades women have been serving in this denomination as its ministers, but yet are still held on the periphery of 'the able' or excluded from it entirely in terms of leadership. In the past 39 years, in 12 Districts, only one woman (the Rev. Purity Malinga) has held the office of Bishop, which she held for three terms of three years, so she was bishop for nine years, which is exceptional in the MCSA policy. The MCSA has also not yet had a woman serve in the office of Presiding Bishop, although it has a woman (The Rev. Charmaine Morgan) serving in the office of the General Secretary. Only a few Districts have yet voted for a woman to serve as a District lay leader.

Even though the MCSA has been ordaining women since 1976, still a vast majority of women ministers do not receive invitations or a call to serve congregations and many need to take the initiative to negotiate their own station. The usual invitation procedure or stationing process, through which the majority of male ministers are placed, ensures that not too many male ministers end up without appointments or stations. However, it does not ensure the same level of protection to women ministers. Women ministers are, therefore, often stationed unjustly in remote and difficult congregations as that is all that is available after the male ministers have chosen the 'cream of the crop'. A woman minister is most likely to be without a station ${ }^{23}$ or has to accept being stationed in a more difficult congregation than a male counterpart.

\section{Statistics on women ministers in leadership structures of the MCSA}

Appendix 1 below illustrates the distribution of women ministers in leadership positions from districts to connexional levels for the period 1976-2015 as stated in the Methodist Yearbook 2015. ${ }^{24}$ It is very clear that few women occupy leadership positions in the MCSA. Women are far fewer in number compared to their male counterparts, and the low numbers of positions they occupy in the church also show lack of intentionality and effort on the side of the church to promote them into positions of leadership. Some districts don't have even a single female minister in their executives. It is also noteworthy that where women do occupy positions, they are secretaries and treasurers.

22 Oosthuizen, Conquerors in Christ, 75.

23 Stationing in the Methodist Church language refers to the appointment of a minister to serve in a circuit (parish) in other terms.

24 The Methodist Church of Southern Africa Yearbook \& Directory 2014-2015, Cape Town: Methodist Publishing House, 53-263. 


\section{THE EXPERIENCE OF ORDAINED WOMEN MINISTERS}

MCSA has been one example of a denomination in which marginalisation and rejection of women have been predominant. These feelings were expressed by the Rev. Ketshabile at Conference when she gave a report on 'Women in Ministry'. She observed:

Although the church has said yes to the ordination of women, the emergence of women who were ready to be ordained did not make things easy for them in the church. The church continued to be hostile to them. Attitudes and practices of a patriarchal culture still continue to hinder the progress of women in this church..$^{25}$

Some examples include, in some Societies, ${ }^{26}$ being excluded from the physical pulpit, which is reserved for ordained ministers or probationers who are male; the persistent assignment of menial or 'gender-suitable' roles in meetings and workshops, such as taking minutes or making tea; being ignored when speaking into a meeting of clergy; and being excluded from consideration for certain stations where patriarchy is very strongly entrenched.

\section{Sexual harassment}

Experiences of sexual harassment and abuse are reportedly not unusual, and include lay male church members as well as male colleagues. A number of women minister's interviewed shared stories of how their male colleagues made sexual advances to them. Some also shared that even the lay leaders in the church harass them as women and they find it difficult to report and find justice from the church because the whole leadership system is male and those in leadership have a tendency of protecting their male colleagues. This leads one to conclude that there is no justice and fairness for women in ministry. There have been cases where women ministers accused of sexual misconduct have faced disciplinary committees almost entirely composed of males, and they have had to defend themselves. When a researcher probed one bishop on this issue, he said that:

I will not deny at all that women ministers have been abused sometimes by their male colleagues. When such cases have been raised we have responded as a church. But most of the time such cases are not reported. On the question of disciplinary panels consisting of male members only, sometimes the reason is that we do not have a big pool of women from where we can choose people for the committees, simply because women are a minority in

25 Rev. Libuseng Ketshabile. Presentation to the 27th Annual Conference of the Methodist Church of Southern Africa. Held from 23-25 September 2016.

26 Society is a Methodist term that refers to the local church or congregation. 
the list of clergy. I agree that as a church we need to be intentional about this if we are going to provide serious support to our women ministers. ${ }^{27}$

The bishop's response to my question revealed the struggle that is faced by the church in responding to the call for support and fairness by women ministers around issues of justice and equality. It is clear that the church has not intentionally deliberated on the support systems that are needed by their women ministers.

\section{Rejection by fellow women in the church}

Patriarchy has dealt a big blow to women. Generally it has made them not to believe in themselves and in one another, but rather for them to believe in the supremacy of male leadership. An example of this is the way in which female members of the congregation respond to the ministry of women. In most cases they are the first to undermine a woman minister. One might expect that women in the church and women's organisations such as the Women's Manyano would support women ministers, but this is often not the case; rather, women in the church tend to indicate a preference for male leadership when it comes to the minister. This should not be surprising, but rather be understood as the outcome of centuries of women's oppression and brain-washing, both from a cultural perspective and a biblical one. Therefore, a number of women who were interviewed reported having experienced lack of support from other women. A few had experienced direct undermining of their work. There is a real struggle which has been caused by issues such as mistrust, insecurity and fear in the MCSA between ministers' wives and women ministers. This struggle is even more prevalent when it comes to the leadership of the Women's Manyano, which is the most powerful body in the church. Traditionally, ministers' wives automatically became leaders of this group. Now that the church has women ministers there is a contestation on who should lead this organisation, a minister's wife or the female minister in the local congregation. A case in hand is the ongoing struggle between the Young Women's Manyano in Limpompo, who have opted for the leadership of their organisation by a women minister by the name of Rev. Dineo Mathibeli, instead of a minister's wife. This has created tension between the two groups. One president of the Women's Manyano at a connexional level, who is a minister's wife, when asked how she felt about women ministers, openly asserted that:

I hate them. In fact I even tell some of them that I hate them. They undermine us as ministers' wives simply because we have not been to the Seminary and so have no theological education. They see us as grabbing the role of leading women in the church. We see ourselves as also being called together with our husbands. We do not see ourselves as lay people but as clergy too. I hate them. ${ }^{28}$

27 Bishop T.W. Dlamini. Natal West District. Interviewed on the 22 August 20116, in Pietermaritzburg. 
These antagonistic feelings between women ministers and ministers' wives are mutual. A few weeks ago the author reported to students at the Seminary that management had taken a decision to train ministers' spouses in theology and ministry, so that they can be able to support their spouses with their work at the local congregation. One female seminarian was quite upset by this and asserted that:

By taking this decision, it is very clear that management is now biased. You have taken a position which supports ministers' wives against women ministers. Why do you have to train them? They have not been called to ministry; they are just being threatened by the fact that women ministers have the education and the ordination. Now you are giving them education. You are biased and this is not fair (sic). ${ }^{29}$

These two engagements make it clear that there is contestation on the ministry of women in the church, especially with regard to leadership. Instead of women working together to fight patriarchy in the church, they are also fighting amongst themselves. Unfortunately this weakens their struggle and delays their victory. To resolve this problem the MCSA needs to encourage theological education on gender matters for all its members and workshops to address gender equality across the membership.

\section{Relegation to subservient roles}

Church structures tend to be dominated by male ministers, almost invariably having a male in the primary leadership position. Such male-dominated structures tend strongly towards a self-perpetuating patriarchal culture. The MCSA analysis of the leadership structures (such as the Connexion Executive, District Executives, Unit management staff and District Disciplinary Committees) (Appendix 1) reveals that this pattern continues. Few women ministers have made it to positions of leadership. Even if they are part of these committees, in most cases women will be requested to play non-leadership roles such as the writing of minutes and looking after the funds, while the influential position of chairperson or president would be reserved for their male colleagues.

\section{Pervasive nature of patriarchy}

One key aspect of the pervasive nature of patriarchy was identified as the commonality of male life experiences, sharing such elements as having attended the same school, or university, enjoying the same sport or supporting the same team, sharing a common cultural tradition, and having a common view of women as inferior. Men already in leadership positions would naturally identify more easily with and would more easily select other men, rather than women, to join them in the leadership structures.

29 I will call this seminarian Nokuthula Mthembu as a coded name. 


\section{TOWARDS THE NEXT 40 YEARS: THE WAY FORWARD}

If the MCSA is going to achieve its goal of enabling women in ordained ministry going forward, it will need to be intentional by implementing practical steps to achieve this noble goal. From the insights gained from this research, the researchers have a few proposals that they would like to make to the church.

\section{Enforcement of the church's policy of equal representation}

It is clear that the MCSA has noticed and acknowledged the problem. In 1999, 23 years after ordaining the first woman minister, Conference passed a resolution requiring that all church structures observe representivity by appointing members to leadership in a ratio of 40:40:20 (women, men and youth).$^{30}$ Over the years the structures of the MCSA have been struggling to comply with this resolution. There is no evidence that any structure has even fully complied with this noble resolution, but rather you see a continuous struggle to comply. In most connexional meetings there are more men represented than women. There is little evidence that the (predominantly male) leadership of the MCSA has ever attempted to enforce this resolution. This is with the exception of Conference 2009, which was held in Pietermaritzburg where the then Presiding Bishop, the Rev. Ivan Abrahams had to be persuaded to declare Conference opened, simply because the election of delegates had not complied with this resolution. He proposed that Conference needed to be postponed and District be instructed to convene Synods in order to elect new delegates to Conference and be compelled to comply with this resolution. For the first time in the history of Conference an attempt was made to take this resolution seriously.

An important observation made from this research is that, because of the inherent bias in the existing structures, it would be necessary to impose change from the top. Organic transformation will not take place within any reasonable period of time unless executive action is taken. Policy changes such as quotas, affirmative action in appointments, and workshops and training to young women researchers are being discussed. This can be suggested as an important measure for the MCSA to take if it wants to speed up the appointment of women into leadership levels.

\section{Recruitment of more women ministers}

The Methodist Church of Southern Africa is at cross-roads for change and transformation, but first it needs to get rid of its hierarchy and patriarchal system that hides behind issues such as culture and tradition. Firstly, towards the next 40

30 Minutes of Conference. Methodist Church of Southern Africa. Cape Town: Methodist Publishing House, 1999, 21. 
years the way forward for the MCSA is that more women ministers need to be recruited within the MCSA. Secondly, more women ministers need to be appointed into senior positions within the church structures, because God calls people equally - irrespective of gender. Thirdly, women ministers need to be incorporated into the round-table for decision-making purposes and not be side-lined. Fourthly, in relation to the right to equality in ordination, the MCSA needs to commit itself to a higher level by drafting and implementing policies that will empower women ministers through the allocation of resources equal to that of male ministers. For the women ministers to succeed towards the next 40 years, firstly they need to get rid of issues such as power, ideology, politics, violence and the issue of sexuality. The Charter of the Mission Congress of the MCSA was adopted in Umtata through its vision emphasises 'A Christ healed Africa for the healing of nations'. ${ }^{31}$

Jesus Christ wanted his disciples to follow and maintain a domination-free relationship that also includes women in the decision-making process; a process that is equal. Therefore, he did not condemn power but how power is used to dominate others. Wink (2009) emphasises that God 'does not reject greatness, but finds it in identification and solidarity with the needy at the bottom of the society' ${ }^{32}$ Therefore, the MCSA through its prophetic voice, needs to be directed by the Holy Spirit to continue the pilgrimage of Obedience 81 and the Journey to the New Land.

The road ahead is not easy because it is full of obstacles, but what is important is that women need to plan and know who they are and begin to understand themselves in what we believe and value. They should be envisioning possible futures that we anticipate will change as we begin to engage with each other. The MCSA needs to strengthen opportunities for the educational purposes of women, whilst meeting commitments and not neglecting the right to equality in the ordination of women ministers. More women ministers should be appointed to become superintendents, bishops, and also be part of the EXCO, so that their voices can be heard across the board within the broader church of the MCSA. The MCSA, by placing and appointing more women ministers in leadership roles within the church structures, will be influencing accountability, responsibility, effectiveness and effective leadership by making the church more relevant and legitimate. The above aspects are all grounded in our relationship with God and therefore the MCSA should envision a strategy of nurturing the relationships of women ministers through a dialogue that creates a trust relationship. Lastly, as the women embark on wrestling the right to equality in ordination, the playing field should be levelled by forming strategic partnerships with the women ministers to make them part and parcel of the decision making within the Methodist Church of Southern Africa. ${ }^{33}$

31 The Mission Charter of the Methodist Church of Southern Africa, 2004.

32 Wink, 2009. When the powers fall: Reconciliation in the healing of nations, 7.

33 Wink, When the powers fall: Reconciliation in the healing of nations, 7. 


\section{Women ministers must be subjects of their struggle}

The women ministers within the MCSA need to own the struggle of equality in ordination and ministry amongst men and women in the MCSA. The quest for power amongst the male ministers needs to be addressed and space must be given for the women ministers to fulfil leadership roles. Wink says that 'Jesus, vision of a domination-free order enables us to see every struggle against injustice, illness, and greed as part of a single front, and gives us a perspective that links us to everyone engaged in similar struggles' ${ }^{34}$ Other people can be in solidarity with them, but they need to lead this struggle, telling their stories and experiences of marginalisation in the church and conscientising other Methodists, men and women, about the theological significance of women ministry in the church.

Therefore, women ministers need to exert more pressure on the connexional structures to strongly voice their opinions on being included within the structures of the church in terms of decision making. Segregation and sexism within the MCSA must come to an end, and the church should begin to recognise women ministers in the same way as they recognise male ministers; doing away with the issue of patriarchy. Women ministers within the MCSA need to equip themselves in terms of studying further, thereby enabling themselves to engage and debate issues that affect them as women ministers. Women ministers need to fight against the entrenched inequality and must be taking their place within the church, fulfilling their rightful position. In order for inequality to be eradicated, women need to support each other and put more pressure on the leadership of the MCSA to listen to the voices of women ministers. The MCSA must be made to see that as a church they cannot survive without women ministers, because women form part and parcel of who the MCSA is. Therefore, the inclusion of women in full ministry of the MCSA, through powerful transformation, may not be fully grasped without first analysing women's self-initiated organisations and their resultant empowerment and support of the marginalised and oppressed in their own church. The MCSA believes and embraces the concept of priesthood of all believers and therefore it is appropriate that it should be practised as such, including women. Therefore, women ministers need to position themselves to help the church move forward for the betterment of change and transformation, and they should begin to compete with their fellow male ministers because they have the same capacity as male ministers to do the job that awaits them. ${ }^{35}$

\section{Include men in the struggle}

The issue of gender inequality is not only a theological one, but also a human rights one; and it has not been solved as yet. Du Toit (2009) says that the "the marginalisation

34 Wink, When the powers fall: Reconciliation in the healing of nations, 11.

35 Wink, When the powers fall: Reconciliation in the healing of nations, 11. 
and oppression of so many women and children throughout the world demands our attention as people of faith'. ${ }^{36}$ Men are the dominant gender and therefore the majority of the women ministers find it very difficult to establish a space for them to operate because of the issue of gender inequality. The MCSA preaches and advocates for peace and justice, but women ministers are yet to see that happening because women ministers do not receive the same justice and equality as their male counterparts. ${ }^{37}$ The struggle for the recognition of women's rights and potential should not be seen and understood as an issue that women alone have to worry about. It is a matter of justice which should concern all people, be they male or female. There is a need to encourage men to become involved in this struggle. Organisations such as the Young Men's Guild and the Men's Association need to be conscientised to participate in this struggle. They should include educational programmes on issues of gender in their Conventions and meetings. The issue of gender inequality within the MCSA cannot be won by women ministers only, but they need to rope in and involve their male counterparts. Men should be included in the struggle for gender equality to dispel the notion of a distortion of the God-intended partnership between male and female, and ultimately to the exclusion of the women from church leadership and even the abuse of women in a Christian home.

\section{CONCLUSION}

This study has highlighted the work and commitment of the MCSA to becoming an inclusive church and exercising an inclusive ministry, which takes into account the equality of men and women's ordination. The church has taken resolutions to include women in ministry and leadership roles. However, it is quite clear that little progress has been made thus far. The majority of women ministers remain unrecognised, unappreciated, underutilised and at most feel abused in the ministry. This is in spite of the fact that women are the backbone and social capital of the MCSA. However, they remain on the margins of the church. Women are underrepresented in the leadership structures of the MCSA especially at the district and connexional level.

It is also very clear that African sub-cultures in the connexion, e.g. Zulu, Sotho, Tswana, Pedi, Swazi, Xhosa and Shangaan, have played a very prominent role in preserving patriarchy in the church, which has resulted in the marginalisation of women. As a result, although women have been the backbone and the life of the church by doing mission work, fundraising and supporting the meetings of the church, they have not been able to break the ceiling as far as leadership is concerned.

36 Du Toit, N. The marginalisation of women and children: Ethical perspectives. In What is a good life? An introduction to Christian ethics in 21st century Africa. Edited by L. Kretzschmar, W. Bentley and A. van Niekerk. Kempton Park: AcadSA Publishing, 2009, 193. 
That is why after 40 years of ordained ministry, the church has had only one female bishop and one female general secretary.

It is the opinion of the researcher (and his colleagues in the research project) that the Methodist Church has not made enough effort to reverse the marginalisation of women in the ordained ministry of the MCSA. This situation is not theologically acceptable for a church that prides itself on 'being one and undivided' and one that has been ordaining women for four decades. The current state of affairs perpetuates injustice against women and deprives the church of their unique quality of leadership. It has also been realised that women ministers have experienced lots of hurt from the church over the years. There is a very clear discrepancy in the MCSA between the hierarchy's commitment to promoting the ministry of women and the practice of pervasive patriarchy at the local churches and structures, which in a subtle way thwarts the efforts of the leadership to promote the leadership of women. We would appreciate the efforts of the MCSA leadership to enable women ministry, whilst at the same time encouraging them to work even harder to make this vision a reality. This can only enhance the integrity of the MCSA and its message of support for the struggle against the oppression of women, both in the church and society.

\section{REFERENCES}

Du Toit, N. 2009. The marginalisation of women and children: Ethical perspectives. In What is a good life? An introduction to Christian ethics in $21^{\text {st }}$ century Africa. Edited by L. Kretzschmar, W. Bentley and A. van Niekerk. Kempton Park: AcadSA Publishing.

Ketshabile, L. 2016. Presentation to the 27th Annual Conference of the Methodist Church of Southern Africa. Held from 23-25 September 2016.

Methodist Church of Southern Africa. 2004. The Mission Charter. Umtata: 24 September.

New Dimension. Celebrating the Rev. Constance Oosthuizen. 2016. New Dimension 47(7): 1.

Oosthuizen, C. 1990. Conquerors through Christ. Cape Town: Galvin \& Sales.

Runyoro, W., Rangarari, R., Erusmus, J. and Hendriks, J. 2001. Resource development and women in leadership position in the Reformed Church of Zimbabwe. Missionalia 29(3), (November 2001): 520-536.

Seth Mokitimi Methodist Seminary Brochure 2016, 21.

The Methodist Church of Southern Africa Yearbook \& Directory 2014-2015, Cape Town: Methodist Publishing House, 53-263

Tucker, R.L.W. 1987. Daughters of the church. Grand Rapids: Academie Books.

Warner, L. The method of our mission: United Methodist polity and organization. Nashville: Abingdon.

Watson, N. 2002. Introducing feminist ecclesiology. London: Bloomsberry Publishers

Wink, W. 2009. When the powers fall: Reconciliation in the healing of the nations. Minneapolis: Fortress Press. 
Winslow, K. 2005. Wesleyan perspectives on women in ministry. Azusa Pacific University.

Yrigoyen, J.C. 1996. John Wesley: Holiness of heart and life. Nashville: Abingdon Press.

\section{APPENDIX 1}

\begin{tabular}{|c|c|c|c|}
\hline Directory & Male & Female & $\%$ \\
\hline Presiding Bishop's Office & 2 & 2 & $50 \%$ \\
\hline Bishops & 13 & 0 & $0 \%$ \\
\hline \multicolumn{4}{|l|}{ District Officials } \\
\hline Cape of Good Hope & 4 & 1 & $25 \%$ \\
\hline Grahamstown & 5 & 0 & $0 \%$ \\
\hline Queenstown & 5 & 0 & $0 \%$ \\
\hline Kimberley, Namibia \& Bloemfontein & 4 & 1 & $25 \%$ \\
\hline Northern Free State \& Lesotho & 3 & 1 & $33 \%$ \\
\hline Natal Coastal & 4 & 1 & $25 \%$ \\
\hline Natal West & 5 & 0 & $0 \%$ \\
\hline Central & 5 & 0 & $0 \%$ \\
\hline Highveld \& Swaziland & 4 & 1 & $25 \%$ \\
\hline Limpopo & 4 & 1 & $25 \%$ \\
\hline Clarkebury & 5 & 0 & $0 \%$ \\
\hline Connexional executive and District lay leaders & 29 & 10 & $34 \%$ \\
\hline Unit directors & 6 & 6 & $50 \%$ \\
\hline District treasurers & 6 & 5 & $80 \%$ \\
\hline District Trust Properties secretary & 10 & 1 & $10 \%$ \\
\hline Connexional Disciplinary Committee & 2 & 3 & $10 \%$ \\
\hline District Disciplinary Registrar & 10 & 1 & $28 \%$ \\
\hline Local Preachers Association & 7 & 2 & $40 \%$ \\
\hline Secretaries & 4 & 7 & $7 \%$ \\
\hline Youth coordinators & 14 & 1 & 33 \\
\hline Conveners of Connexional Committees & 6 & 2 & $6 \%$ \\
\hline Superintendents & 284 & 17 & \\
\hline
\end{tabular}

